\title{
SUSCEPTIBILITY ASSESSMENT OF WATERMELON AND PUMPKIN CULTIVARS TO POTYVIRUS IN TOCANTINS
}

\author{
AVALIAÇÃO DA SUSCEPTIBILIDADE DE CULTIVARES DE MELANCIA E \\ ABÓBORA A POTYVIRUS OBTIDOS DO ESTADO DE TOCANTINS
}

\section{Marcio Akio OOTANI ${ }^{1}$; Raimundo Wagner de Souza AGUIAR ${ }^{2}$; Gabriela Priscila de Sousa MACIEL ${ }^{3}$; Francisca Luana de Araujo CARVALHO ${ }^{4}$; Larissa Alves LOPES ${ }^{5}$; Marielle Peres EVANGELISTA ${ }^{6}$}

1. Doutor em Agronomia/Fitotecnia Universidade Federal do Ceara - UFC, Fortaleza, CE, Brasil, ootani667@uft.edu.br; 2. Professor, Doutor, Departamento de Biologia Molecular Universidade Federal do Tocantins - UFT, Gurupi, TO, Brasil; 3. Graduanda em Agronomia Universidade Federal do Ceara - UFC, Fortaleza, CE, Brasil; 4. Mestranda em Zootecnia Universidade Federal do Piaui - UFPI, Teresina, PI, Brasil; 5. Mestranda em Bioquímica, Universidade Federal do Ceara - UFC, Fortaleza, CE, Brasil; 6. Mestrado em Produção Vegetal Universidade Federal do Tocantins - UFT, Gurupi, TO, Brasil,

\begin{abstract}
Cucurbits cultivation has great importance in the food industry. However, in the main producing regions of curcubits, the increase of cultivation areas has been limited by viral infections. Among the most prevalent viruses there is the Watermelon Mosaic Virus (WMV), Papaya Ringspot Virus (PRSV-W) and Zucchini Yellow Mosaic Virus (ZYMV). The aim of this study was to evaluate the reaction of watermelon genotypes (Crimson sweet and Charleston Gray) and pumpkin (Jacarezinho and Caserta) to isolate watermelon strains in the following cities: Palmas (PYP-12), Gurupi (PYG-14 and PYG-19), Formoso do Araguaia (PYF-6), and Porto Nacional (PyPn-36 and PyPn-39). The experiment was performed in a greenhouse, in a completely randomized design, with 5 testing plants for each repetition to measure the response of these strains to cucurbit genotypes. The inoculated strains were obtained from leaves of watermelon cv Crinson sweet with symptoms The plants were rated by severity of viral symptoms in intervals of four days during 32 days. It was verified that the cucurbit genotypes showed different susceptibility to the viral strains. However, Caserta and Charleston gray were the ones which had greater sensitivity due to their high severity variation among the tested strains. Thus, it can be observed that the reaction among strains depends on the host and this reaction can be antagonistic or synergistic, depending on the mixed infection. Charleston gray watermelon was the most susceptible to most of the viral strains. Thus, this cultivar should be avoided in these regions.
\end{abstract}

KEYWORDS: Citrullus lanatus. Cucurbita pepo. Viral diseases.

\section{INTRODUCTION}

Among the cucurbits cultivated in Tocantins, watermelon (Citrullus lanatus (Thunb.) Matsum \& Nakai) and pumpkin (Cucurbita pepo) (AGUIAR et al., 2015) have an important place (DA COSTA et al., 2013). However, the cucurbit production in this region has shown high susceptibility to several diseases. Among these diseases, there are some caused by viruses which have been responsible for relevant production losses (BESERRA et al., 2007).

The genus Potyvirus has three relevant species for the cucurbit cultivation: Papaya ringspot virus strain watermelon (PRSV-W) (RAZEAN HAIREEN; DREW, 2014), Watermelon mosaic virus (WMV) (ELBESHEHY et al., 2015) and Zucchini yellow mosaic virus (ZYMV) (LECOQ et al. 2009). These viruses are transmitted in a nonpersistent way through several species of aphids, including Myzus persicae and Aphis spp. (STOBBS et al., 2015). The infected plants may show symptoms such as mosaic, reduction of the foliar limb and leaf deformation which significantly reduce crop yield and also affect the fruit quality (REZENDEZ et al., 1999).

These diseases severity can vary according to the pathogen, host, vector and environment interaction (KOTZAMPIGIKIS et al., 2010). Moreover, the occurrence of mixed infection, in which different viruses strains infect the same plant, can result in more complex symptoms, leading to production losses. The viruses can infect cucurbit in all the development stages. However, the losses are larger when the infection occurs during seedling phase (VAN MUNSTER et al., 2003).

In several locations worldwide, most of the economic losses in cucurbit production are associated to viral diseases. The location has been associated to the virus predominance, since there are different strains of viruses in each region. Thus, in Brazil, PRSV and ZYMV were predominant in the region of São Francisco valley (SILVEIRA et al., 2009), in the state of São Paulo (REGATIER et al., 2008) and Maranhão state (MOURA et al., 2001). According to Halfeld-Vieira et al. (2004), in 
Roraima, there are PRSV-W, WMV and ZYMV in simple and mixed infections.

The aim of the present study was to evaluate the reaction of watermelon and pumpkin genotypes to isolates with single, double and triple infections, obtained from watermelon crops in the regions of Formoso do Araguaia, Porto Nacional, Gurupi and Palmas.

\section{MATERIAL AND METHODS}

The experiment was performed in a greenhouse at the Federal University of Tocantins Gurupi in 2010-2011. The viral samples were collected in the producer regions: Palmas (PyP-12), Gurupi (PyG-14 e PyG-19), Formoso do Araguaia (PyF-6) and Porto Nacional (PyPn-36 e PyPn-39). The leaves were placed in kraft paper bags and conditioned in coolers under the temperature of $4^{\circ} \mathrm{C}$, at the phytopathology laboratory.

The identification of the viruses was performed by the serological test of Dot-ELISA, with specific antisera for WMV-II, ZYMV and PRSV-W, according to Aguiar et al. (2015). The samples were macerated and prepared according to the procedures used by Banttari \& Goodwin (1985). All the results obtained from the samples were compared to the results obtained from the controls (healthy plants with symptoms of the respective viruses).

The cultivars were sown in Styrofoam trays and after the emergence of four definitive leaves, they were transplanted into five-liter pots with substrate. The mechanic inoculations were performed during the cotyledonary phase. The first one was performed in the phase with two definitive leaves and the second, three days after the first inoculation. Infected leaf tissues of Caserta pumpkin in a monophasic and biphasic phosphate buffer 0,01 $\mathrm{M}, \mathrm{pH}$ 7,0 and sodium sulfite were used as inoculum in both procedures. The viral solution was obtained by maceration in the proportion of $1 \mathrm{~g}$ of infected leaf tissue and $2 \mathrm{~mL}$ of inoculation buffer. The inoculations were performed through friction of gauze soaked with the viral suspension in the presence of carborundum (400 mesh), previously sprayed on the leaves (MORENO et al., 2012). After inoculation, the plants were maintained in a greenhouse. The study was carried out in a completely randomized design with 5 replications per isolated viruses, for two watermelon cultivars (Crimson sweet and Charleston Gray) and two pumpkin cultivars (Caserta and Jacarezinho).

The evaluations started eight days after the first inoculation and the symptoms were assessed every four days, based on a severity rating proposed by Rezende (1996) where: (1) plants without mosaic symptoms on the leaves; (2) plants with few leaves with mosaic symptoms on the edges; (3) plants with mosaic symptoms in many leaves; (4) plants with mosaic symptoms in most leaves, many bubbles and/or leaves presenting slight deformation; and (5) plants with intense mosaic symptoms, presence of bubbles and severe deformation. The means were submitted to regression analysis for the function $\mathrm{Y}=$ $a+b \mathrm{x}$, then the means of the regression parameters $a$ and $b$ were compared by Tukey test with $5 \%$ of probability using the software Sisvar 5.8 (FERREIRA, 2011).

The symptoms caused by the viral infections were determined according to a classification system in which: M: Mosaic; Re: ruffled edges; Bl: bubbles; Sr: spur; Ln: leaf narrowing; Ld leaf deformation; Lr: leafroll; Ud: underdevelopment; Ef: early flowering; Sl: shoelace; Ml: Mottled; Ns: No symptoms. Data were obtained in a period of 32 days after the second inoculation. The symptoms of the disease were based on phenotypic standards of leaves of watermelon and pumpkin, according to Desbiez (2010).

\section{RESULTS AND DISCUSSION}

Through ELISA serological identification method, all the potyviruses that attack cucurbit were identified. WMV was identified as the one with the highest prevalence in all samples. Besides, variation between regions was also observed (Table 1), where samples of PyPn of-36 (WMV, ZYMV) PYP-12 (WMV), PYF-6 (WMV), PYG-14 (WMV), PyPn-39 (WMV; PRSV-W) and PYG-19 (WMV; PRSV-W, ZYMV) showed single, double and triple infections (Table 1). Visual symptoms in Crimson sweet, Charleston Gray, Caserta and Jacarezinho manifested in variable forms when they were inoculated with viral strains for each cucurbits.

Based on the visual evaluations in Caserta, the PyG-19 strain, which was positive for WMV; PRSV-W; ZYMV, reached maximum severity according to Figure 1. (A, C and D), showing plants with more severe symptoms of virus, such as leaf deformation (Lf), underdevelopment (Ud), mosaic (M) and leaf narrowing (Ln). During the evaluations, these factors were not observed in other strains which did not get grades higher than 4, showing less sensitivity, especially for PyG- 14 ,which showed less severity when inoculated with potyvirus (Figures 1. B, C). 
Table 1. Serological identification of Papaya ringspot Watermelon-virus (PRSV-W), Watermelon mosaic virus (WMV) and Zucchini yellow mosaic virus (ZYMV) in leaf samples of watermelon species in production areas in Tocantins.

\begin{tabular}{llll}
\hline Strains & PRSV-W & WMV & ZYMV \\
\hline PyPn-36 & - & + & + \\
PyP-12 & - & + & - \\
PyF-6 & - & + & - \\
PyG-14 & - & + & - \\
PyPn-39 & + & + & - \\
PyG-19 & + & + & + \\
Control & - & - & - \\
\hline
\end{tabular}

* (-) negative for viral species (+) positive for viral species.
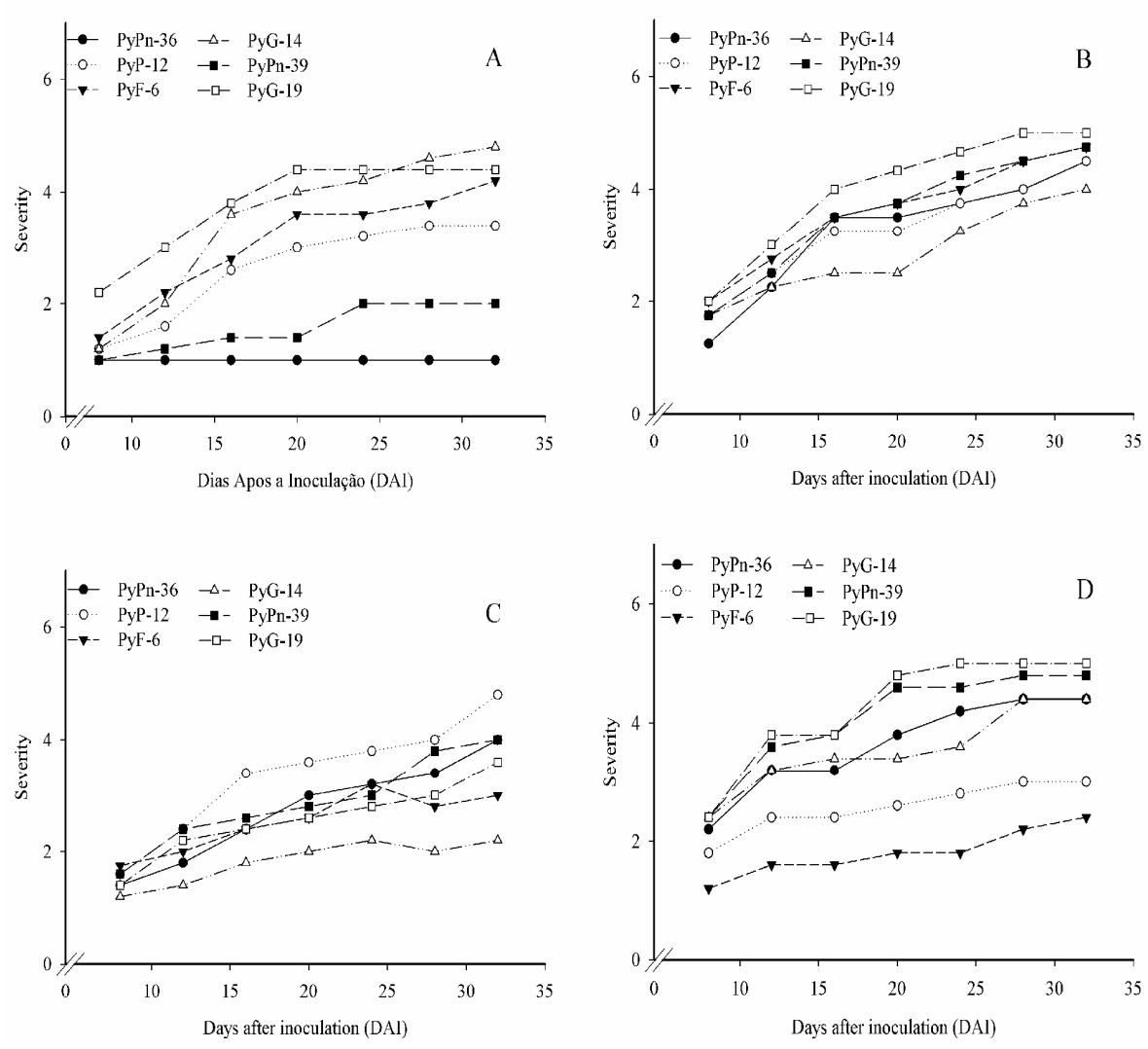

Figure 1. Average severity as a function of time for different strains: Palms (PyP-12), Gurupi (PyG-14 and PyG-19), Formoso Araguaia (PyF-6) and National port (PyPn-36 and PyPn-39). A - Caserta pumpkin, B- Jacarezinho pumpkin, C - Crimson sweet watermelon and D - Charleston Gray watermelon.

However, there were no significant differences among the strains compared to the means by Tukey test (Table 2). In the Charleston gray cultivar, the higher susceptibility was observed in PyG-19 strain where the presence of the three analyzed viral strains (PRSV-W, WMV and ZYMV) was observed, with maximum severity on the $24^{\text {th }}$ day after inoculation (DAI). PyF-6 strain was positive only for WMV and demonstrated the lowest severity (less than two). The most severe symptoms were represented by plants with bubbles, mosaic and underdevelopment. Unlike what was found in Crimson watermelon, the strain PyP-12 was the least pathogenic from the beginning to the end of the evaluation (Figure $1 \mathrm{C}$ ). 
Table 2. Summary of linear regression analyzes $(\mathrm{Y}=b+a \mathrm{x})$ of the susceptibility of cucurbit genotypes to different viral strains obtained from four cities in Tocantins.

\begin{tabular}{|c|c|c|c|c|c|c|c|}
\hline & & Paramet & & & & & \\
\hline Genotypes & Strain & $\bar{a}$ & $b$ & GL & $\bar{F}$ & $\mathrm{R}^{2}$ & $\mathrm{P}$ \\
\hline Caserta & PyPn-36 & $0.000 \mathrm{c}$ & $1.000 \mathrm{bc}$ & 5 & ------- & 1.00 & $\begin{array}{l}------- \\
\end{array}$ \\
\hline Caserta & PyP-12 & $0.160 \mathrm{a}$ & $0.830 \mathrm{bc}$ & 5 & 40.89 & $0.93 * *$ & 0.0019 \\
\hline Caserta & PyF-6 & $0.170 \mathrm{a}$ & $1.470 \mathrm{ab}$ & 5 & 71.33 & $0.95 * *$ & 0.0007 \\
\hline Caserta & PyG-14 & $0.140 \mathrm{a}$ & $2.010 \mathrm{a}$ & 5 & 49.03 & $0.93 * *$ & 0.0018 \\
\hline Caserta & PyPn-39 & $0.040 \mathrm{bc}$ & $1.050 \mathrm{bc}$ & 5 & 58.97 & $0.94 * *$ & 0.0011 \\
\hline Caserta & PyG-19 & $0.060 \mathrm{~b}$ & $1.820 \mathrm{a}$ & 5 & 42.01 & $0.87 * *$ & 0.0095 \\
\hline Average & & $0.095 \mathrm{~A}$ & $1.363 \mathrm{~A}$ & & & & \\
\hline $\mathrm{CV} \%$ & & 21.00 & 20.94 & & & & \\
\hline Jacarezinho & PyPn-36 & $0.120 \mathrm{ab}$ & $1.270 \mathrm{a}$ & 5 & 32.83 & $0.93 * *$ & 0.0023 \\
\hline Jacarezinho & PyP-12 & $0.110 \mathrm{ab}$ & $1.370 \mathrm{a}$ & 5 & 99.50 & $0.97 * *$ & 0.0002 \\
\hline Jacarezinho & PyF-6 & $0.090 \mathrm{~b}$ & $1.730 \mathrm{a}$ & 5 & 108.15 & $0.97 * *$ & 0.0001 \\
\hline Jacarezinho & PyG-14 & $0.120 \mathrm{ab}$ & $1.530 \mathrm{a}$ & 5 & 116.05 & $0.97 * *$ & 0.0001 \\
\hline Jacarezinho & PyPn-39 & $0.120 \mathrm{ab}$ & $1.400 \mathrm{a}$ & 5 & 73.06 & $0.96 * *$ & 0.0004 \\
\hline Jacarezinho & PyG-19 & $0.130 \mathrm{a}$ & $1.770 \mathrm{a}$ & 5 & 37.69 & $0.93 * *$ & 0.0017 \\
\hline Average & & $0.115 \mathrm{~A}$ & $1.511 \mathrm{~A}$ & & & & \\
\hline CV\% & & 12.84 & 23.10 & & & & \\
\hline Crimson Sweet & PyPn-36 & $0.110 \mathrm{a}$ & $1.060 \mathrm{a}$ & 5 & 200.05 & $0.98 * *$ & 0.0001 \\
\hline Crimson Sweet & PyP-12 & $0.090 \mathrm{ab}$ & $1.420 \mathrm{a}$ & 5 & 58.54 & $0.95 * *$ & 0.0006 \\
\hline Crimson Sweet & PyF-6 & $0.050 \mathrm{bc}$ & $1.370 \mathrm{a}$ & 5 & 22.30 & $0.90 * *$ & 0.0052 \\
\hline Crimson Sweet & PyG-14 & $0.040 \mathrm{c}$ & $1.240 \mathrm{a}$ & 5 & 23.82 & $0.90 * *$ & 0.0045 \\
\hline Crimson Sweet & PyPn-39 & $0.090 \mathrm{ab}$ & $1.400 \mathrm{a}$ & 5 & 93.88 & $0.97 * *$ & 0.0002 \\
\hline Crimson Sweet & PyG-19 & $0.080 \mathrm{ab}$ & $2.310 \mathrm{~b}$ & 5 & 68.48 & $0.96 * *$ & 0.0004 \\
\hline Average & & $0.076 \mathrm{~A}$ & $1.466 \mathrm{~A}$ & & & & \\
\hline $\mathrm{CV} \%$ & & 26.69 & 14.05 & & & & \\
\hline Charleston Gray & PyPn-36 & $0.100 \mathrm{~b}$ & $2.690 \mathrm{a}$ & 5 & 46.64 & $0.95 * *$ & 0.0010 \\
\hline Charleston Gray & PyP-12 & $0.070 \mathrm{~b}$ & $1.480 \mathrm{a}$ & 5 & 44.47 & $0.94 * *$ & 0.0011 \\
\hline Charleston Gray & PyF-6 & $0.170 \mathrm{a}$ & $1.320 \mathrm{a}$ & 5 & 66.48 & $0.96 * *$ & 0.0005 \\
\hline Charleston Gray & PyG-14 & $0.050 \mathrm{~b}$ & $1.850 \mathrm{a}$ & 5 & 44.66 & $0.94 * *$ & 0.0011 \\
\hline Charleston Gray & PyPn-39 & $0.060 \mathrm{~b}$ & $2.770 \mathrm{a}$ & 5 & 22.83 & $0.90 * *$ & 0.0050 \\
\hline Charleston Gray & PyG-19 & $0.080 \mathrm{~b}$ & $2.810 \mathrm{a}$ & 5 & 23.65 & $0.92 * *$ & 0.0067 \\
\hline Average & & $0.088 \mathrm{~A}$ & $2.153 \mathrm{~B}$ & & & & \\
\hline $\mathrm{CV} \%$ & & 33.08 & 25.95 & & & & \\
\hline
\end{tabular}

$*$ and $* *$ significant by the $\mathrm{F}$ test of the regression at $1 \%$ and $5 \%$ probability, respectively; Means of the regression parameters followed by the same lowercase letter for strains and upper case for genotypes do not differ statistically by Tukey test at $5 \%$ probability.

Among the pumpkins genotypes, the cultivar Caserta was highly sensitive to PyF-6, PyPn-36, PyP-12, PyG-14 and PyG-19 strains, with symptoms such as mild mosaic in the first evaluation. Thus, over the evaluation period, there was a trend of severity evolution for watermelon and pumpkin genotypes reaching top marks on the $24^{\text {th }}$ day after inoculation, with a total deformation of leaves and appearance of severe symptoms such as shoelace, spur and enation. On the other hand, it was observed that PyPn-36 strain showed multiple virus (ZYMV and WMV), in which no viral symptoms were observed. This low severity of symptoms may be associated with the antagonistic 
relationship. The difference between the evaluated strains is evident through the means test performed in the regression parameters (Table 2).

Jacarezinho pumpkin showed susceptibility to all inoculated strains, and it was observed a gradual increase in severity after inoculation, with early symptoms reaching severity grade of 2 in the $8^{\text {th }}$ day after inoculation. However, the PYG-39 strain that presents interaction between the two viral strains (PRSV-W + WMV) was more severe in all evaluations, where the symptoms were already visible on the $5^{\text {th }}$ DAI with mosaic on the edges and small bubbles. Overall, samples showed symptoms such as bubbles, leaf deformation, mosaic, shoelace and spurs. Comparing Caserta and Jacarezinho, it is verified a difference in the severity among strains (Table 1). The results observed in this study corroborate with other results of viral infection in cucurbits (ROMAY et al., 2014), demonstrating that the virus severity in species of cucurbit is very dynamic, varying according to virus and strains, climate condition, population, vectors migration, vegetal variety and natural reservoirs of predominant virus (AGUIAR et al., 2015).

In the assessment of the isolates collected in Gurupi, the most severe mixed infections were observed in the pumpkins genotypes. Caserta and Charleston gray had greater susceptibility in PyG-19 strain, where the presence of the three viral strains (PRSV-W, WMV and ZYMV) was observed. For simple infection, PyG-14 strain (WMV) showed the most severe symptoms only for Caserta pumpkin plants, showing symptoms such as mosaic, deformed leaf, leaf narrowing and bubbles (Figure 2., Table 3).

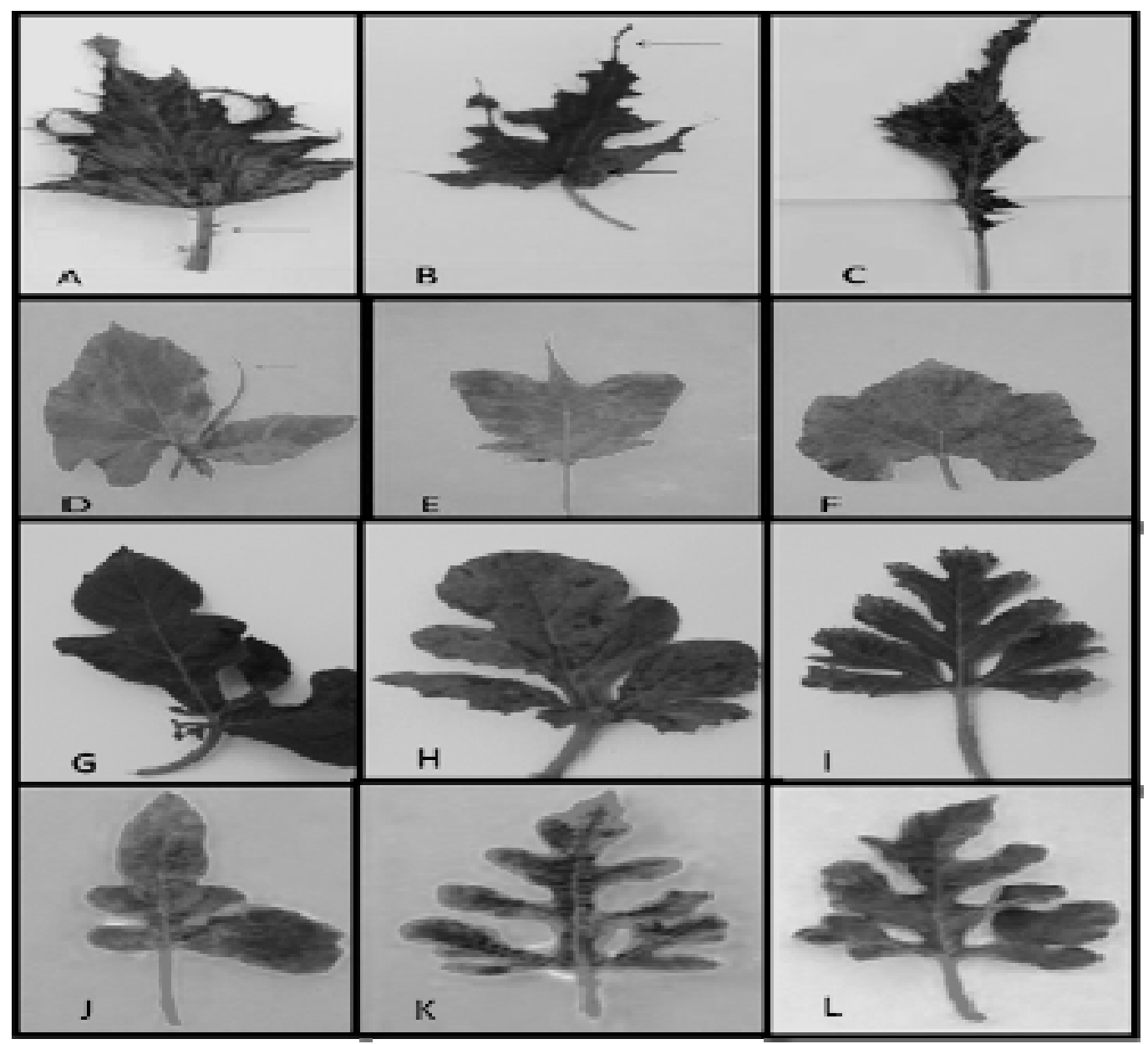

Figure 2. Phenotypic symptoms observed in Caserta Pumpkin: A, Spur (Sr) and Mosaic (M); B, Shoelace (Sl); C, Bubble (Bl). Leaf deformation (Ld) and Leaf narrowing (Ln). Symptoms observed in Jacarezinho pumpkin: D, Shoelace (Sl) and Leaf deformation (Ld); E, Spur (Sr) and Leaf narrowing (Ln); F, Mosaic (M) and Bubble (Bl). Symptoms observed in Charleston Gray watermelon: G, Leaf deformation-Ld; H, Bubble-Bl, Mosaic (M) and Leaf narrowing (Ln); I, Light mosaic (Lm). Symptoms observed in Crimson Sweet watermelon: J, Leaf deformation (Ld); K, Mosaic (M) and Bubble (Bl); L, Light mosaic (Lm). 
Table 3. Symptomatology of the strains inoculated in two watermelon and pumpkim genotypes

\begin{tabular}{|c|c|c|c|c|}
\hline \multirow{2}{*}{ Strain } & \multicolumn{4}{|c|}{ Symptomatology } \\
\hline & Crinson sweet & Charkeston gray & Caserta & Jacarezinho \\
\hline PyPn-36wz & Lm, Bl, Ld, Ud. & M, Bl, Ld Ud. & Ns. & Lm, Bl, Ld. \\
\hline PyP-12w & M; Lr; Ld; Ud. & M; Df; Ml. & $\begin{array}{l}\text { M; Re;Lr; Bl; Ld; } \\
\text { Ud. }\end{array}$ & M, Re; Sl, Ld. \\
\hline PyF-6w & M, Re, Lr, Sl, Ld. & M, Re, Ln, Sl, Ld. & M; Bl; Ld; Ud; Ml. & M, Re; Sl, Ld. \\
\hline PyG-14w & M, Re,Ln, Sl, Ld. & M, Re, Ln, Sl, Ld. & M; Ln; Ld; Ud. & M, Bf,; Sl, Ld. \\
\hline PyPn-39pw & M; Re; Ln; Ld; Ud. & $\begin{array}{l}\text { M; Lr; Re; Bl; Ld; } \\
\text { Ud. }\end{array}$ & $\begin{array}{l}\text { M; Ln; Re; Bl; Ld; } \\
\text { Sr; S.l; Ud; }\end{array}$ & M; Lr; Ef; Ud. \\
\hline PyG-19wzp & $\begin{array}{l}\text { M; Re; Bl; Ln; Ld; } \\
\text { Ef; Ud; Ml. }\end{array}$ & $\begin{array}{l}\text { M; Re; Bl; Ld; Ef; } \\
\text { Ud; Ml }\end{array}$ & $\begin{array}{l}\mathrm{M} ; \mathrm{Re} ; \mathrm{Bl} ; \mathrm{Ld} ; \mathrm{Ef} ; \\
\mathrm{Ud} ; \mathrm{Sr} ; \mathrm{Sl} ; \mathrm{Ml}\end{array}$ & $\begin{array}{l}\text { M; Bl; Ld; Ef; Ud; } \\
\text { Ml. }\end{array}$ \\
\hline Control & Ns & Ns & Ns & Ns \\
\hline
\end{tabular}

*Symptoms: M: Mosaic; Re: ruffled edges; Bl: bubble; Sr: spur; Ln: leaf narrowing; Ld: leaf deformation; Lr: leaf roll; Ud: underdevelopment; Ef: early flowering; $\mathrm{Ml}=$ Mottled; $\mathrm{Sl}=$ Shoelaces; Ns: no symptoms.

In Gurupi, the mixed infections have been very severe for pumpkin plants, totally compromising the plant growth. According to Mandakombo et al. (2013), in most cases, the symptoms caused by the interaction of two viruses in mixed infection are much more severe and different from those found in single infections, which indicates synergism between these viruses, increasing viral replication capacity and systemic dissemination in the infected plant.

In the evaluation of the isolates in Porto Nacional, two strains (PyPn-36 and PyPn-39) with mixed infections, more severe in pumpkin plants were WMV + PRSV-W and another featuring many less severe symptoms WMV + ZYMV, totally compromising the plant growth (Table 3). According to Aguiar et al. (2015) who studied mixed infections of PRSV + ZYMV in Charleston Gray watermelon and Caserta pumpkin, an increase in symptoms severity and symptoms of plant and leaf underdevelopment, mosaic, bubbles, leaf deformation and shoelace were observed. In Crimson Sweet, the symptoms presented by plants with double infection were much more severe than those presented by PRSV (single), and with greater intensity than those presented by ZYMV (single).

Results in synergistic increases of plant diseases are the product of the expression of the HC-Pro gene, associated with a non-coding RNA sequence. They were sufficient to enhance viral replication (HASIOW-JAROSZEWSKA et al.,
2014). Even so, data of this study showed similar results for the purposes of double infected plants with TuMV P1 and LIYV in transgenic host with HC-Pro. These data suggest that the TuMV activity probably mediates increased accumulation of LIYV in the plant protoplast, which can be one of the factors that help to limit infections for phloem tissue (WANG et al., 2015). However, studies have shown an eight times increase in cells infected in phloem, shown to Potato leaf roll virus (PLRV) in Potato a virus (PVA) in transgenic plants HC-Pro (TU et al., 2015).

The occurrence prevalence of single and mixed infections of potyvirus PRSV-W, ZYMV and WMV in the State of Tocantins, differed between regions (ALVES et al., 2014). Several studies have shown that PRSV-W has a high incidence in cucurbit crops in the Northeast of Brazil (DO NASCIMENTO et al., 2012.). For some authors, this prevalence may be influenced by biotic and abiotic factors and the high activity of the potyvirus for cucurbits (IBABA et al., 2015). Studies conducted in different regions of Brazil have shown high prevalence of PRSV-W and ZYMV in cucurbits, followed by Olarte Castillo et al. (2011).

According to Yakoubi et al. (2008), the predominance of PRSV-W was probably due to its virulence and plant $\mathrm{x}$ vector interaction. Several studies have reported differences in the interactions between viruses in laboratory and field conditions associated with the host plant and the interaction 
between the insect and vector. Crop residues, presence of cultivars susceptible to potyvirus group, and inefficient control practices may have favored the prevalence of potyvirus in watermelon production areas in Tocantins (AGUIAR et al., 2015).

When the virus is installed in the field, it is a very difficult problem to solve because there are no measures to control the virus. The earlier the plant is infected, the more severe will be the symptoms and the losses in production will be greater.

\section{CONCLUSION}

Charleston gray watermelon was the most susceptible to most of the viral strains. Thus, this cultivar should be avoided in these regions.

RESUMO: O cultivo de cucurbitáceas tem grande importância no que diz respeito à alimentação, mas o aumento das áreas de plantio tem sido limitado por infecções virais nos principais pólos produtores de cucurbitáceas. Entre os mais prevalentes destacam-se o vírus do mosaico da melancia (WMV), o vírus da mancha anelar do mamoeiro estirpe melancia (PRSV-W) e o vírus do mosaico amarelo da abobora (ZYMV). Este estudo teve como objetivo avaliar a reação dos genótipos de cucurbitácea Melancia Crimson sweet e Charleston gray; Abóbora: Jacarezinho e Caserta, para isolar variedades de safra de melancia nas cidades de Palmas (PYP-12), Gurupi (PYG-14 e PYG-19), Formoso do Araguaia (PYF-6) e Porto Nacional (PyPn-36 e PyPn-39). O experimento delineamento inteiramente casualizado (DIC), foi conduzido em estufa e foram utilizadas 5 plantas de teste para cada repetição para medir a resposta dessas cepas aos genótipos de cucurbitáceas. A inoculação dos vírus em plantas realizada a partir de folhas com a infecção de melancia Crimson sweet. As plantas inoculadas foram avaliadas por graus de severidade em quatro dias de intervalo durante 32 dias após a inoculação. Verificou-se que os genótipos de cucurbitaceas analisadas apresentaram susceptibilidade diferente às cepas virais testadas. No entanto, o genótipo de abóbora de Caserta e Charleston gray foram as que apresentou maior sensibilidade, devido à sua alta variação de severidade entre as cepas. Assim, podemos ver que a reação entre as estirpes depende do hospedeiro e a reação pode ser antagonista ou sinérgica dependendo da infecção mista. A melancia Charleston gray foi o mais suscetível à maioria das cepas virais. Assim, esta cultivar deve ser evitada nessas regiões.

PALAVRAS-CHAVE: Citrullus lanatus. Cucurbita pepo. Viroses

\section{REFERENCES}

AGUIAR, R. W. S.; RODRIGUES, A.; PORTELLA, A. C. F.; LOPES, M. M.; LIMA, M. F.; R.O., R.; NAGATA, T. Serological Identification of Virus in Watermelon Production Fields in the Tocantins State. Brazilian archives of biology and technology, Curitiba, v. 58, n. 2, p. 192-197, Mar/Apr 2015.

ALVES, A. F.; DO NASCIMENTO, I. R.; TICONA-BENAVENTE, C. A.; FARIA, M. V.; SARMENTO, R. D.; FIGUEIRA, A. D.; MALUF, W. R. Inheritance of the resistance of the watermelon accession PI 595201 to a PRSV-W isolate from the State of Tocantins. Bragantia, Campinas, v. 73, n. 2, p. 138-142, Jun 2014. https://doi.org/10.1590/brag.2014.022

BANTTARI, E. E.; GOODWIN, P. H. Detection of Potato Virus-S, Virus-X, and Virus-Y by Enzyme-Linked Immunosorbent-Assay on Nitrocellulose Membranes (Dot-Elisa). Plant Disease, Minnesota, v. 69, n. 3, p. 202205, Oct 1985.

BESERRA, J. E.; FIGUEIRA, A. D.; MALUF, W. R. Selection of resistant watermelon lines to Watermelon mosaic virus and Papaya ringspot virus. Ciencia e Agrotecnologia, Lavras, v. 31, n. 5, p. 1563-1568, Sept./Oct 2007.

DA COSTA, A. R. F. C.; DE MEDEIROS, J. F.; PORTO, F. D.; DA SILVA, J. S.; COSTA, F. G. B.; DE FREITAS, D. C. Production and quality of watermelon cultivated with water of different salinities and doses of nitrogen. Revista Brasileira De Egenharia Agricola e Ambiental, Campina Grande, v. 17, n. 9, p. 947-954, Sept 2013. 
DESBIEZ, C.; GIRARD, M.; LECOQ, H. A novel natural mutation in HC-Pro responsible for mild symptomatology of Zucchini yellow mosaic virus (ZYMV, Potyvirus) in cucurbits. Archives of Virology, Springer Vienna, v. 155, n. 3, p. 397-401, Jan 2010. https://doi.org/10.1007/s00705-009-0569-4

DO NASCIMENTO, I. R.; DOS SANTOS, L. B.; SARMENTO, R. D.; FIGUEIRA, A. D.; DE OLIVEIRA, G. I. S.; AGUIAR, R. W. D. Phenotypic Reaction of Cucurbita spp. Genotypes to Pappaya ringspot virus, watermelon strain - PRSV-W. Bioscience Journal, Uberlandia, v. 28, n. 2, p. 191-197, Mar./Apr 2012.

ELBESHEHY, E. K. F.; YOUSSEF, S. A.; ELAZZAZY, A. M. Resistance induction in pumpkin Cucurbita maxima L. against Watermelon mosaic potyvirus by plant growth-promoting rhizobacteria. Biocontrol Science and Technology, v. 25, n. 5, p. 525-542, Dec 2015. https://doi.org/10.1080/09583157.2014.994198

HALFELD-VIEIRA, B. A.; RAMOS, N. F.; RABELO FILHO, F. A. C.; GONÇALVES, M. F. B.; NECHET, K. L.; PEREIRA, P. R. V. S.; LIMA, J. A. A. Identificação sorológica de espécies de potyvirus em melancia, no estado de Roraima. Fitopatologia Brasileira, Visçosa, v. 29, p. 687-689, 2004.

HASIOW-JAROSZEWSKA, B.; FARES, M. A.; ELENA, S. F. Molecular Evolution of Viral Multifunctional Proteins: The Case of Potyvirus HC-Pro. Journal of Molecular Evolution, Springer US, v. 78, n. 1, p. 75-86, Nov 2014.

IBABA, J. D.; LAING, M. D.; GUBBA, A. First Report of a Novel Potyvirus from the Papaya ringspot virus Cluster Infecting Zucchini (Cucurbita pepo) in KwaZulu-Natal, Republic of South Africa. Plant Disease, Minnesota, v. 99, n. 9, p. 1289-1290, 2015.

KOTZAMPIGIKIS, A.; HRISTOVA, D.; TASHEVA-TERZIEVA, E. Virus-Vector Relationship between Potato Leafroll Virus Plrv and Myzus Persicae Sulzer. Bulgarian Journal of Agricultural Science, v. 16, n. 4, p. 412-421, Aug 2010.

LECOQ, H.; WIPF-SCHEIBEL, C.; CHANDEYSSON, C.; LE VAN, A.; FABRE, F.; DESBIEZ, C. Molecular epidemiology of Zucchini yellow mosaic virus in France: an historical overview. Virus Research, v. 141, n. 2, p. 190-200, Jan 2009. https://doi.org/10.1016/j.virusres.2008.11.020

MOURA, M. C. C. L.; LIMA, J. A. A.; OLIVEIRA, V. B.; GONÇALVES, M. F. B. Identificação sorológica de espécies de vírus que infetam cucurbitáceas em áreas produtoras do maranhão. Revista brasileira de fitopatologia, Visçosa, v. 26, n. 1, p. 90-92, Jan 2001.

MORENO, A.; TJALLINGII, W. F.; FERNANDEZ-MATA, G.; FERERES, A. Differences in the mechanism of inoculation between a semi-persistent and a non-persistent aphid-transmitted plant virus. Journal General Virology, United Kingdom , v. 93, n. 3, p. 662-7, Mar 2012. https://doi.org/10.1099/vir.0.037887-0

OLARTE CASTILLO, X. A.; FERMIN, G.; TABIMA, J.; ROJAS, Y.; TENNANT, P. F.; FUCHS, M.; SIERRA, R.; BERNAL, A. J.; RESTREPO, S. Phylogeography and molecular epidemiology of Papaya ringspot virus. Virus Research, v. 159, n. 2, p. 132-140, Aug 2011.

https://doi.org/10.1016/j.virusres.2011.04.011

RAZEAN HAIREEN, M. R.; DREW, R. A. Isolation and Characterisation of PRSV-P Resistance Genes in Carica and Vasconcellea. International Journal of Genomics, v. 2014, p. 145403, Aug 2014. https://doi.org/10.1155/2014/145403

REGATIER, L. J.; GASPAR, J. O.; BELINTANI, P.; YUKI, V. A. Identification and characterization of a potyvirus isolated from siratro plants. Journal of Phytopathology, v. 156, n. 4, p. 214-216, Jan 2008. https://doi.org/10.1111/j.1439-0434.2007.01342.x 
REZENDEZ, J. A. M.; PACHECO, D. A.; IEMMA, A. F. Effects of cross protection with mild strains of PRSV-W on 'Menina Brasileira' squash. Pesquisa Agropecuaria Brasileira, Brasilia, v. 34, n. 8, p. 1481-1489, Aug 1999.

ROMAY, G.; LECOQ, H.; DESBIEZ, C. Zucchini tigr, mosaic virus is a distinct potyvirus in the papaya ringspot virus cluster: molecular and biological insights. Archives of Virology, Springer Vienna, v. 159, n. 2, p. 277-289, Aug 2014.

SILVEIRA, L. M.; QUEIROZ, M. A.; LIMAJ.A.A.;; NASCIMENTO, A. K. Q.; NETO, I. S. L. Levantamento sorológico de vírus em espécies de cucurbitáceas na região do submédio São Francisco, Brasil. Tropical Plant Pathology, Universidade Federal de Visçosa, Visçosa, v. 34, n. 2, p. 123-126, Jan 2009.

STOBBS, L. W.; LOWERY, D. T.; SAMARA, R.; GREIG, N.; VICKERS, P. M.; BITTNER, L. A. Development of a detached leaf procedure to evaluate susceptibility to Plum pox virus infection by the green peach aphid (Myzus persicae (Sulzer)) in peach. Canadian Journal of Plant Pathology, v. 37, n. 2, p. 230236, April 2015. https://doi.org/10.1080/07060661.2015.1035753

TU, Y.; ZHANG, Z.; LI, D.; LI, H.; DONG, J.; WANG, T. Potato virus Y HC-Pro Reduces the ATPase Activity of NtMinD, Which Results in Enlarged Chloroplasts in HC-Pro Transgenic Tobacco. PLoS One, San Francisco, California, US, v. 10, n. 8, p. 136-210, Aug 2015. https://doi.org/10.1371/journal.pone.0136210

VAN MUNSTER, M.; DULLEMANS, A. M.; VERBEEK, M.; VAN DEN HEUVEL, J. F.; REINBOLD, C.; BRAULT, V.; CLERIVET, A.; VAN DER WILK, F. A new virus infecting Myzus persicae has a genome organization similar to the species of the genus Densovirus. Journal of General Virology, v. 84, n. 1, p. 16572, Jan 2003. https://doi.org/10.1099/vir.0.18650-0

WANG, Z.; JIANG, D.; ZHANG, C.; TAN, H.; LI, Y.; LV, S.; HOU, X.; CUI, X. Genome-wide identification of turnip mosaic virus-responsive microRNAs in non-heading Chinese cabbage by high-throughput sequencing. Gene, v. 571, n. 2, p. 178-187, Jun 2015. https://doi.org/10.1016/j.gene.2015.06.047

YAKOUBI, S.; LECOQ, H.; DESBIEZ, C. Algerian watermelon mosaic virus (AWMV): a new potyvirus species in the PRSV cluster. Virus Genes, Springer US, v. 37, n. 1, p. 103-109, May 2008.

https://doi.org/10.1007/s11262-008-0237-x 